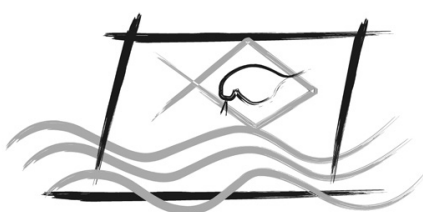

ECOTOX - BRASIL

\title{
Ecotoxicological evaluation of Glyphosate use in controlling $E$. crassipes e Salvinia sp. macrophytes
}

\author{
Maria, M.A. ${ }^{1,2}$; Castro, S.R. ${ }^{3} ;$ Lange, L.C. ${ }^{2}$; Siúves, C.L.F. ${ }^{1}$; e Silva, C De L. ${ }^{4}$; \\ CARneiro, M.H. ${ }^{1} \&$ Vieira, J.O. ${ }^{1}$ \\ ${ }^{1}$ Institute SENAI of Technology in Environment - Innovation and Technology Center Senai Fiemg, José Cândido da Silveira 2000 \\ Avenue - Horto, 31035-536 - Belo Horizonte - MG, Brazil. \\ ${ }^{2}$ Department of Sanitary and Environmental Engineering - Federal University of Minas Gerais - UFMG, Belo Horizonte/MG, Brazil \\ ${ }^{3}$ Department of Sanitary and Environmental Engineering - Federal University of Juiz de Fora - UFJF, Juiz de Fora/MG, Brazil \\ ${ }^{4}$ Vrije Universiteit Amsterdam - VU, Netherlands, Europe
}

(Received August 12, 2017; Accept September 28, 2017)

\begin{abstract}
The present work aimed to carry out traditional ecotoxicological and ecosystemic tests in microcosms for the evaluation of the use of glyphosate herbicide adopted to control floating aquatic macrophytes in aquatic ecosystems. Ecotoxicity tests were performed using standardized methodology and standard species of different trophic levels. Although the active ingredient glyphosate is toxic, the toxicity of its commercial formulation is higher. The inert ingredient of the Roundup Original ${ }^{\mathbb{B}}$ composition may be responsible for the higher commercial compound toxicity. Experiments in microcosms indicated that the use of the formulation is possible, in considering tested concentration and controlling the spray process, without causing toxic effect on the aquatic ecosystem. Complementary studies evidenced the risk of using the product in aquatic environments without vegetation cover, being not recommended the herbicide application in a place without floating aquatic macrophytes cover.
\end{abstract}

Keywords: acute toxicity, aquatic ecosystem, chronic toxicity, microcosms, herbicide.

\section{INTRODUÇÃO}

Aquatic macrophytes are a group of plants that live in water bodies, which may be submerged or floating, often of fast proliferation, showing a greater capacity of ecological adaptation. This fact allows the same species to colonize the most different types of environments, what facilitates its wide geographical distribution, being considered in a general way, a cosmopolitan group (Trindade et al., 2010).

Macrophytes control in reservoirs is economically important due to the damages caused in the generation of energy by the hydroelectric plants. The most common way of control of macrophytes is the manual and mechanized withdrawal, which generates high costs, not always with satisfactory results. There are currently three control methods in use: mechanical, chemical and biological. Chemical methods are less accepted by society, due to the risk associated with the toxicity of the products that are applied.

On July 2015, the Resolution ${ }^{\circ} 467$ of CONAMA (National Environment Council) was published, providing criterias for the authorization of the use of products or processes, for the control of organisms or contaminants in surface water. In addition, it establishes the need for a detailed analysis of the risks of the intended intervention, considering the peculiarities of the aquatic environment and the multiple uses of its resources. It also shall be considering the risk management, precautions, safety measurements, mitigating periods and finally, and possible effects of the intended method. 
Glyphosate based herbicides are the most used herbicides in the United States, and adopted, adopted around the world. There is an urgent need to understand the effects of herbicides based on glyphosate in non-target wildlife for the assessment of regulations concerning their use (Levis \& Johnson, 2015).

Glyphosate is widely used in Brazil and is indicated for the control of annual and perennial weeds, monocotyledons or dicotyledons, and is indicated for different cultures (Amarante Jr. et al., 2002). According to Facchini (2007) Brazil is one of the world leaders in pesticide consumption.

There is an increasing concern about the impact of these herbicides in the aquatic environment, since data on the toxicity on fish and other aquatic organism is limited. It is necessary to carry out studies evaluating different environments and the effect of exposing animals to concentrations of herbicides over time (Rocha et al., 2015).

Ecotoxicology studies the adverse effects of toxic substances on communities and species in an ecosystem, and can be performed through acute and chronic bioassays or ecosystem assessments. It is a science of great relevance for assessing the environmental risk of substances and products before its commercialization, being an important tool for environmental monitoring.

Ecotoxicological evaluations may be performed on air, soil, sediment and water. There are many studies about glyphosate toxicity evaluation in soil, since its main use has been in agriculture. However, in the face of increasing concerns about its use in water bodies, to control floating aquatic macrophytes, it became necessary to analyze its toxicity in the aquatic ecosystem.

Vera et al. (2010) reported the toxicity on non-target organisms and water quality derived from the use of herbicides in agriculture, attributing toxic effects to Roundup due to changes in the structure and function of freshwater ecosystems with the reduction of periphyton growth in affected areas.

According to Rocha et al (2015), herbicides can induce environmental stress in aquatic organisms, as well as damaging fish respiratory system by reducing oxygen absorption, absorption, which leads to hypoxia.

In Southeast Asia, Yusof (2014) conducted ecotoxicological assays with fish cultured in laboratory, evaluating: survival, embryo hatch rate, changes in heart beating rate and morphological deficiencies. The author verified, that survival and hatching rate decreased with the increasing concentrations of glyphosate and that such changes can be used as an early warning tool for glyphosate contamination in coastal areas of the tropical region, being an effective way of assessing water toxicity.

Pesce (2009) detected effects on algae community composition and diversity of the eukaryotic community only in samples collected during summer. This work demonstrates that even if the effects of a short pulse of glyphosate on microorganisms appear to be limited, the responses of natural microbial communities exposed to glyphosate (and probably other pesticide risks) may vary clearly between different experiments.

Silva et al. (2014) experiments showed that glyphosate caused harmful effects on the reproductive parameters of Danio rerio males with the drastic fertility reduction caused by the decrease of sperm motility, and the reduction of mitochondrial membrane integrity and function. Authors such as Arenzon (2011) and Bertoletti (2009), reported similar effects as the one presented on Danio rerio (Silva et al., 2014) on Poecilia reticulata, a species traditionally adopted in ecotoxicological assays in Brazil.

According to Amarante Jr et al. (2002), fish and aquatic invertebrates are the most sensitive organisms to glyphosate and other ingredients of their commercial formulation, followed by bacteria, fungi and some soil invertebrates, including mites.

Costa and Nomura (2016), carried out toxicity studies of environments contaminated by a commercial formulation based on glyphosate and verified the decline of native amphibian species populations, which are highly susceptible to glyphosate contamination.

The toxicity of herbicides based on glyphosate can also be produced by other chemical components of their formulation, which are not usually referred by the manufacturers. For example, the Roundup Original ${ }^{\circledR}$ contains $68.4 \%$ of inert ingredient. According to Vera et al. (2012) it is difficult to know the true mechanism of action of these formulations on the environment since the chemical composition of the mixtures is unknown.

Tsui et al. (2005) report that glyphosate toxicity on the aquatic system is mainly due to the presence of a surfactant in the Roundup commercial formulation. Studies of Sihtmae et al. (2013) also reported the surfactant problem, supposing that glyphosate is more toxic due to the additives that are present in the formulations.

The surfactant has an important function in the action of the herbicide, facilitating the action of the active ingredient, allowing the application of doses. According to Haberkorn et al. (2008), the surfactant may retain the herbicide on the water surface of the aquarium and on the surface of the plant, being the main pathway for its disappearance in the water.

Due to the complexity of the product to be tested and considering the chemical composition, molecular interactions in the environment and physical-chemical variations, it is necessary to carry out studies that are more realistic. According to Arenzon (2011), to carry out ecotoxicological tests, even standardized ones, there is always a concern to reproduce the effects on the field into the laboratory, and it can be done by new approaches, as in situ tests but also with the use of native species that are more representative of the study sites.

Mikó et al. (2015) investigated the importance of the experimental site for ecotoxicological studies and demonstrated considerable discrepancies between classic laboratory test results and mesocosms experiments. 
Mesocosms studies suggest that assessments based on standard laboratory tests cannot always adequately predict the effects on populations, or at community level, in the natural environment. Unfortunately, similar studies comparing the effects of pesticides on different test sites are scarce (Mikó et al, 2015).

Ecosystem assessments are studies with a systemic approach that has been called stress ecology. In this view the concept of ecological niche assumes great importance and the study becomes more realistic. They are multi-species trials, such as in meso and microcosms, in addition to traditional tests, evaluating in a reduced approach the behavioral effects and not only the survival, growth and reproduction of a single (Magalhães and Ferrão Filho, 2008).

Thereby, the aim of this work was to carry out traditional ecotoxicological and systemic microcosms tests to evaluate the toxicity of Roundup Original ${ }^{\circledR}$, a glyphosate herbicide on the control of floating aquatic macrophytes in aquatic ecosystems.

\section{MATERIAL AND METHODS}

Acute and chronic ecotoxicological tests were performed with microcrustaceans and bacteria using: commercial formulation (Roundup Original $^{\circledR}$ ); glyphosate standard; AMPA standard (its metabolite) of purity $99.7 \%$ Sigma Aldrich, Brazil; Iharaguen's ${ }^{\circledR}$ surfactant and microcosms samples. Ecotoxicological tests were also carried out at the end of the experiments in microcosms for the sediment, with the same species, using elutriate extract according to ABNT NBR 15.469:2007. During twenty days of experimentation in microcosms, systemic ecotoxicological evaluations were also carried out.

Toxicity acute tests were carried out based on standardized methodology and standard species of different trophic levels: Daphnia simillis (ABNT NBR 12.713:2016) and Aliivibrio fischeri (ABNT NBR 15.411-2:2012).

The result of the acute test was presented through the initial median effective concentration, $\mathrm{CE}(\mathrm{I})_{50}$, which is $48 \mathrm{~h}$ for $D$. similis and 5 to 30 minutes for $A$. fischeri. For $D$. similis, the observed effect was immobility and/or mortality, determined through the statistical analysis using the software PROBIT 1.5. For the bacteria $A$. fischeri, the evaluation of the assay was performed by decreasing luminescence, considering a correlation factor, which is a measure of the luminescence changes of the control during the exposure period. This last calculation was performed by the Omni software (Microtox ${ }^{\circledR}$ M500 System Analyzer luminometer), using the lyophilized biomass of Biolux ${ }^{\circledR}$ NRRL-B-11177.

Chronic ecotoxicity was evaluated using a single species, Ceriodaphnia dubia, based on ABNT NBR 13.373: 2016 methodology. Using this protocol, it was possible to establish the CENO (I) (initial concentration of unobserved effect) and CEO (I) (initial concentration of observed effect), which allowed the calculation of VC (I) (initial chronic value) by the geometric mean between the two measures; these were obtained over statistical analysis using the software TOXTAT 3.3.

The quantification of glyphosate has been carried out in Metrohm Chromatograph, model Professional IC with sampler 850, dozino, columns Supp 7 250/4.0 and Supp 1 Guard/4.6. The method consists of a binary gradient that allowed the simultaneous analysis of glyphosate and AMPA in the same run, with a retention time of up to 35 minutes and a detection limit of $20 \mu \mathrm{g} \mathrm{L}^{-1}$ for glyphosate and $100 \mu \mathrm{g} \mathrm{L}^{-1}$ for AMPA, quantification limit of $60 \mu \mathrm{g} \mathrm{L}^{-1}$ for glyphosate and $200 \mu \mathrm{g} \mathrm{L}^{-1}$ for AMPA. The method was worked with white subtraction to reduce noise that could impair detection of AMPA. The methodology developed by Metrohm (ABE, 2014) was applied with some adaptations.

\section{Ecotoxicological tests with substances and products}

Working solutions were prepared at the concentrations of $50 \mathrm{mg} \mathrm{L}^{-1}$ for glyphosate standard and AMPA; $50 \mathrm{~mL}$ $\mathrm{L}^{-1}$ to Roundup (18 g e.a.L $\left.\mathrm{L}^{-1}\right)$; and $1 \mathrm{~mL} . \mathrm{L}^{-1}$ for Iharaguen's ${ }^{\circledR}$ (Polyoxyethylene alkylphenol ether).

For these solutions, acute bioassays were performed with D. similis, A. fischeri and chronic bioassays with C. dubia.

\section{Ecotoxicological tests with microcosm samples}

Lagoon microcosms were performed in order to evaluate the control of individuals of the species Eichhornia crassipes (Mart.) Solms (1883) and Salvinia sp., floating aquatic macrophytes using the Roundup Original ${ }^{\circledR}$ formulation.

Microcosms were built in a standardized way, simulating a lagoon (geographical coordinate 19053'15.702 'S $\left.43^{\circ} 54^{\prime} 57.906^{\prime \prime} \mathrm{O}\right)$, which was the sampling point for water $(35 \mathrm{~L})$ and sediment $(4 \mathrm{~kg})$ used in the microcosms. A column of sediment column and water with 2 and $20 \mathrm{~cm}$, respectively, was obtained, totalizing $22 \mathrm{~cm}$.

Eight individuals of $E$. crassipes, having $70 \mathrm{~g}$ mean mass each, were placed, totalizing $560 \mathrm{~g}$; or $300 \mathrm{~g}$ of Salvinia sp. per aquarium. Besides that, each aquarium was composed with ten snails, ten individuals of Poecilia sp. and ten individuals of Danio rerio. All the aquariums had lateral isolation with kraft paper, and were kept in a room (laboratory) with controlled temperature $\left(23 \pm 2{ }^{\circ} \mathrm{C}\right)$, luminosity (3000 lux) and photoperiod (16 hours light and 8 hours dark).

It is worth pointing out that all microcosms were assembled and stabilized using sufficient amount of floating aquatic macrophyte to cover the whole water surface.

The experiments were performed in triplicate for each macrophyte species and control, and were kept for twenty days spiked only once with a single concentration of Roundup Original ${ }^{\circledR}$ of $100 \mathrm{~L} \mathrm{ha}^{-1}$, applied by spraying.

For each aquarium, water sample was taken every five days and, at the end of the $20^{\text {th }}$ day a sediment sample was taken. This sample was used in the acute toxicity tests with $D$. similis, A. fischeri and chronic test with C. dubia. 
In order to allow for it was used the standardized methodology, following in full the ABNT technical standards, being performed sensitivity tests with reference substances for each of the organisms used in the bioassays.

\section{Systemic ecotoxicological evaluation}

For the systemic ecotoxicological evaluation, no samples were collected and it was not used autochthonous bioindicator in the environment, prevailing only the observation of the effect in the organisms.

The test was performed for fifty days, being divided in two steps. The first 20 days, there were no interventions. The 30 days left for the test to finish, daily observation of 10 minutes was performed in each aquarium. During this period, the behavior of fish, snails and the development of the vegetal species were observed.

For Danio rerio there is a standardized procedure for ecotoxicological tests (ABNT NBR 15.499: 2016) and for fish of the Poecilia reticulata species there isn't, however they are also used in ecotoxicological tests. According to Bertoletti (2009) this species is as sensitive as the Danio rerio and can replace native species in acute toxicity tests with substances and liquid effluents.

This evaluation could also be named global ecotoxicity, since the behavior, survival and reproduction of all living organisms in the environment was observed throughout the experimental period.

\section{Complementary ecotoxicological evaluations}

In a complementary analysis of the ecosystem smaller aquariums with $3 \mathrm{~L}$ capacity and $0.0154 \mathrm{~m}^{2}$ surface area were used, with its laterals covered with kraft paper (brown paper), using the water and sediment samples from the lagoon. The experiments were assembled in triplicate, twice for confirmation, with one of them filled with $2.5 \mathrm{~L}$ of water, $250 \mathrm{~g}$ of sediments, 3 fish of Poecilia $\mathrm{sp}$. and 1 individual of E. crassipes. The other experiment had the same composition, with the exception of the portion of sediments and macrophyte.

Roundup Original ${ }^{\circledR}$ was applied in all experiments at the concentration of $100 \mathrm{~L} \mathrm{ha}^{-1}$.

\section{Sensitivity of test organisms}

The sensitivity of all test organisms was evaluated with reference substances to each new experimentation batch. $D$. similis, $C$. dubia, $D$. rerio and $P$. reticulata using sodium chloride and $A$. fischeri was tested with phenol and zinc sulfate, as established by the technical standards.

\section{RESULTS}

Table 1 presents the Initial Chronic Value (VC(I)) for C.dubia, and the Effective Concentration $\left(\mathrm{CE}(\mathrm{I})_{50}\right)$ for $D$. similis and $A$. fischeri, has the ecotoxicological tests results for the substances used in this study. It is important to highlight that glyphosate is the equivalent for Roundup Original ${ }^{\mathbb{R}}$ and polyoxyethylene alkylphenol ether is the equivalent for Iharaguen's ${ }^{\circledR}$.

The results showed that both glyphosate and its metabolite, AMPA, presented chronic and acute toxicity for all tested organisms. It was also verified that, when compared to the AMPA results, glyphosate presented higher acute toxicity for D. similis and A. fischeri, with CE(I) of $35.13 \mathrm{mg} \mathrm{L}^{-1}$ and 11.46 $\mathrm{mg} \mathrm{L}^{-1}$, respectively; and lower chronic toxicity for C. dubia, with $\mathrm{VC}(\mathrm{I})$ equal to $28.72 \mathrm{mg} \mathrm{L}^{-1}$, around 1.5 times higher.

When comparing acute and chronic data from the pure compound and its metabolite with the formulation, the later proved to be more toxic for $C$. dubia and D. similis, with VC(I) of $5.76 \mathrm{mg}$ e.a. $\mathrm{L}^{-1}$ and $\mathrm{CE}(\mathrm{I})_{50}$ of $9.00 \mathrm{mg}$ e.a. $\mathrm{L}^{-1}$, respectively. But when comparing the toxicity of the compounds for A. fisheri the order changes with the pure compound being the most toxic one, followed by its metabolite, and the formulation being the last toxic (Table 1). Considering that only $36 \%$ of Roundup is composed by glyphosate, additional ingredients, of the formulation could influence its toxicity. One of the ingredients that raise concerns is the surfactant. This hypothesis could be corroborated by the high toxicity of Iharaguen's, which presented lower values of VC(I) for $C$. dubia and $\mathrm{CE}(\mathrm{I})_{50}$ for D. similis (Table 1). A. fisheri was an exception regarding the toxicity, being more tolerant to the compounds tested rather the other species, probably because it is a marine bacterium with less sensitivity.

The increasing sequence of sensitivity for $C$. dubia was Glyphosate < AMPA < Roundup < Iharaguen's; for $D$. similis: AMPA < Glyphosate < Roundup < Iharaguen's; and for $A$. fischeri: Iharaguen's $<$ AMPA $<$ Roundup $<$ Glyphosate.

The acute and chronic toxicity values expressed in $\mathrm{CE}(\mathrm{I})_{50}$ and VC(I) in Table 1 had an inverse relationship, this is, the lower this value the higher the toxicity, since the results were expressed in terms of concentration. The graphical representation facilitates the understanding, and the result

Table 1 - Chronic and acute ecotoxicological results for glyphosate, AMPA, Roundup and Iharaguen's solutions

\begin{tabular}{|c|c|c|c|}
\hline Sample & C. dubia - VC(I) & D. similis - $\mathrm{CE}(\mathrm{I})_{50}$ & A. fischeri- $\mathrm{CE}(\mathrm{I})_{50}$ \\
\hline Glyphosate & $28.72 \mathrm{mg} . \mathrm{L}^{-1}$ & $35.13 \mathrm{mg} . \mathrm{L}^{-1}$ & $11.46 \mathrm{mg} . \mathrm{L}^{-1}$ \\
\hline AMPA & $17.68 \mathrm{mg} . \mathrm{L}^{-1}$ & $52.80 \mathrm{mg} . \mathrm{L}^{-1}$ & $20.25 \mathrm{mg} . \mathrm{L}^{-1}$ \\
\hline Roundup & $5.76 \mathrm{mg}$ e.a.. $\mathrm{L}^{-1}$ & $9.00 \mathrm{mg}$ e.a. $\mathrm{L}^{-1}$ & $20.16 \mathrm{mg}$ e.a. $\mathrm{L}^{-1}$ \\
\hline Iharaguen's & $2.80 \mathrm{mg}$ e.a.. $\mathrm{L}^{-1}$ & 5.80 mg e.a.L $\mathrm{L}^{-1}$ & $59.560 \mathrm{mg}$ e.a. $\mathrm{L}^{-1}$ \\
\hline
\end{tabular}


of the acute toxicity with A. fischeri for Iharaguen's was not expressed due to its reduced toxicity $\left(\mathrm{CE}(\mathrm{I})_{50}\right.$ equal to 59.560 $\mathrm{mg}$ e.a. $\left.\mathrm{L}^{-1}\right)$ which would impair the visualization of the other results (Figure 1).

These results were important to highlight the relevance of making the correct choice of the test organisms when conducting an ecotoxicological assay. Based on the results, it was possible verify that $A$. fischeri does not presented proper sensitivity for the evaluation of the Roundup Original ${ }^{\mathbb{B}}$ and Iharaguen' $\mathrm{s}^{\circledR}$ toxicity, not being recommended for environmental monitoring, or management of areas where these products has been applied.

For the microcosm experiment, $1.8 \mathrm{~mL}$ of Roundup Original $^{\circledR}$ was applied, which is equivalent to $648 \mathrm{mg}$ of glyphosate, resulting in a final concentration of $18.5 \mathrm{mg}$ e.a. $\mathrm{L}^{-1}$, after complete mixing with the water $(35 \mathrm{~L})$ of the aquarium. The initial concentrations of the first microcosms sampling after herbicide application, had the highest values, ranging from 13.8 to $38.6 \mathrm{mg} \mathrm{L}^{-1}$ with a $19.7 \mathrm{mg} \mathrm{L}^{-1}$ average. This concentration was higher than the toxicity values obtained by Roundup for C. dubia and D. similis, $5.76 \mathrm{mg}$ e.a. $\mathrm{L}^{-1}$ and $9.00 \mathrm{mg}$ e.a. $\mathrm{L}^{-1}$, respectively, and lower than the toxicity values obtained by the glyphosate standard for $C$. dubia and D. similis, equals to $28.72 \mathrm{mg} \mathrm{L}^{-1}$ and $35.13 \mathrm{mg}$ $\mathrm{L}^{-1}$, respectively. Only the sample with the highest glyphosate concentration quantified in water $\left(38.6 \mathrm{mg} \mathrm{L}^{-1}\right)$ had a chronic toxic effect for C. dubia with VC(I) of $70.7 \%$ and acute toxic effect for $D$. similis with $\mathrm{CE}(\mathrm{I})_{50}$ of $81.8 \%$. There was no evidence of chronic or acute toxicity in any of the other water samples (samples collected in microcosms 5, 10, 15 and 20

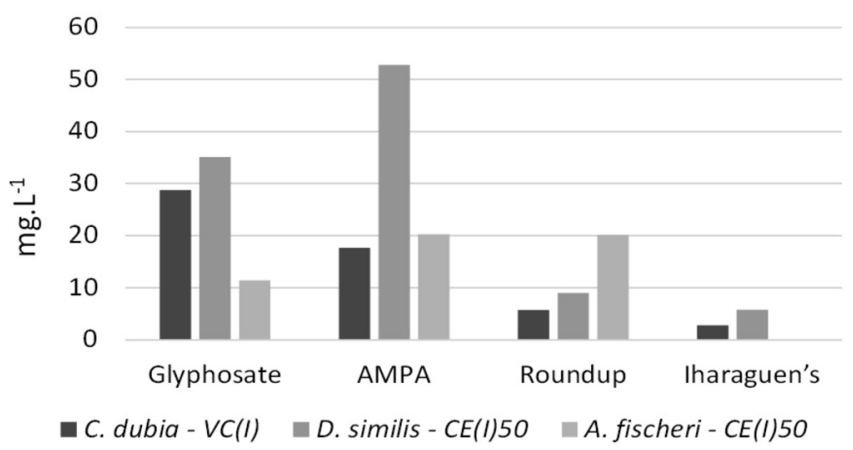

Fig. 1 - Chronic and acute toxicity results of the tested substances days after application), as well as in the sediment collected in the microcosms (Table 2).

Even using the commercial formulation, the concentration that caused toxicity in the water samples refers to the toxic concentration of the glyphosate and not to that of the Roundup, evidencing the previous removal of the component of greater toxicity present in the formulation by the contact with the macrophytes.

It is known that during the sprinkling part of the solution is lost by drift, another part, the one that reaches the aquarium might be retained in the surface of the leaves of the macrophytes, and only a lower concentration of the compound reaches the water system. The surfactant, in particular, tends to be trapped in the surface of the leaves and in the surfaces of the aquarium, which avoid it from reaching the water system, and therefore it may contribute to the reduced toxicity on the aquatic ecosystem. It is noteworthy that all microcosms had floating aquatic macrophytes covering the entire surface of the water.

During the evaluation of the species, no changes in behavior were observed for fish $(D$. rerio and $P$. reticulata $)$ and snails, however, during the first 20 days of the experiment, it was not possible to observe reproduction and the mortality rate was relatively low $(\leq 20 \%)$, equivalent to the control. During the sequential observation period, both groups again reproduced, and at the end of the experiments (50 days), individuals of different age groups were identified. This result corroborates with the ones reported in Vera et al. (2014) regarding the effects on reproduction of $D$. rerio, however there are indication that these effects can be reversed. There is a necessity to consider the evaluation of mutations and problems with the development in long term. Molluscs response to the compound(s) showed a low toxicity to the studied species, and that in unfavorable conditions they moved through the structure of the aquarium in an attempt evade the contaminated water. This fact was not observed during the experimental period when the molluscs moved freely within the water column.

However, in the experiments with E. crassipes, other groups, such as algae and macrophytes, demonstrated changes that were not toxicity indicative, but responses to environment that led to the predominance of different species that coexisted in a relative equilibrium. The decline in numbers of some species, favored others that used to coexist in equilibrium. With the death of the E. crassipes, an opening in the surface

Table 2 - Chronic and acute ecotoxicological results for the samples of microcosms and the average of the glyphosate concentration of the same

\begin{tabular}{|c|c|c|c|c|}
\hline $\begin{array}{l}\text { Sample } \\
\text { (after application) }\end{array}$ & $\begin{array}{c}\text { Glyphosate average } \\
\left(\mathrm{mg} . \mathrm{L}^{-1}\right)\end{array}$ & C. dubia - VC(I) & D. similis - CE $(\mathrm{I})_{50}$ & $\begin{array}{l}\text { A. fischeri - } \\
\text { CE(I) })_{50}\end{array}$ \\
\hline Water - 4 hours & 19.31 & $70.7 \%^{\circ}$ & $81.8 \%{ }^{\circ}$ & $\mathrm{NT}^{*}$ \\
\hline Water $-5^{\text {th }}$ days & 11.79 & $\mathrm{NT}^{*}$ & $\mathrm{NT}^{*}$ & $\mathrm{NT}^{*}$ \\
\hline Water $-10^{\text {th }}$ days & 6.68 & $\mathrm{NT}^{*}$ & $\mathrm{NT}^{*}$ & $\mathrm{NT}^{*}$ \\
\hline Water $-15^{\text {th }}$ days & 4.67 & $\mathrm{NT}^{*}$ & $\mathrm{NT}^{*}$ & $\mathrm{NT}^{*}$ \\
\hline Water $-20^{\text {th }}$ days & 3.66 & $\mathrm{NT}^{*}$ & $\mathrm{NT}^{*}$ & $\mathrm{NT}^{*}$ \\
\hline Sediment $-20^{\text {th }}$ day & 0.96 & $\mathrm{NT}^{*}$ & $\mathrm{NT}^{*}$ & $\mathrm{NT}^{*}$ \\
\hline
\end{tabular}


Table 3 - Chronic and acute ecotoxicological results of the organisms' sensitivity tests (mean \pm standard deviation)

\begin{tabular}{lccc}
\hline Substance & C. dubia $-\mathrm{VC}(\mathrm{I})$ & D. similis $-\mathrm{CE}(\mathrm{I})_{50}$ & A. fischeri $-\mathrm{CE}(\mathrm{I})_{50}$ \\
\hline Sodium Chloride & 0.60 g. $\mathrm{L}^{-1} \pm 0.13$ & 1.83 g. $\mathrm{L}^{-1} \pm 0.23$ & - \\
Phenol & - & - & $21.40 \mathrm{mg} . \mathrm{L}^{-1} \pm 2.46$ \\
Zinc sulfate & - & - & $7.73 \mathrm{mg} . \mathrm{L}^{-1} \pm 2.29$ \\
\hline
\end{tabular}

of the water allowed the growth of periphyton and minor macrophytes, like the Lemna sp. that are used as test organisms in ecotoxicological assays, as described by the Chemical Compounds guide of the Organization for Economic Cooperation and Development (OECD, 2006).

The aim of the complementary experiments was to identify the toxicity of the herbicides sprayed in an area without macrophyte cover, having as a result the death of fish species, in less than 3 hours after application, otherwise in the aquariums containing macrophytes, no alteration in survival or changes in behavior was observed.

Chronic and acute standard tests were performed with the samples from the experiments where the survival rate of the fish species occurred. The sample caused chronic toxicity to C. dubia with VC(I) of $70.7 \%$ and acute to D. similis with $\mathrm{CE}(\mathrm{I})_{50}$ of $36.9 \%$, showing no acute toxicity to A. fischeri.

Glyphosate quantification in the aquarium water was performed immediately after fish death, being $(9.6 \pm 0.3) \mathrm{mg}$ $\mathrm{L}^{-1}$ and a new experiment was set up with the same conditions: $2.5 \mathrm{~L}$ of water and 3 fish species of the Poecilia sp., adding the following concentrations of glyphosate standard $10 \mathrm{mg} \mathrm{L}^{-1}$ and $20 \mathrm{mg} \mathrm{L}^{-1}$. In this experiment, nor survival nor changes in behavior were affected, indicating that the greater toxicity of Roundup Original ${ }^{\circledR}$ comes from the surfactant that, in cases of vegetal cover, is retained on the leaf surface, not reaching the water in toxic concentration. The experiment evidenced the toxicity of Roundup Original ${ }^{\circledR}$ when it was applied in an uncovered area, without floating aquatic macrophytes.

The results of the sensitivity tests are presented in Table 3. The test organisms presented stable sensitivity. The organisms of $C$. dubia and D. similis were grown in laboratory under controlled conditions, this fact provided groups of individuals with approximate sensitivities to sodium chloride, presenting VC(I) $0.60 \mathrm{~g} \mathrm{~L}^{-1}$ and $\mathrm{CE}(\mathrm{I})_{50}$ de $1.83 \mathrm{~g} \mathrm{~L}^{-1}$, respectively. $A$. fischeri strains used reacted appropriately to the reference substances, phenol and zinc sulfate, with mean $\mathrm{CE}(\mathrm{I})_{50}$ values of $21.40 \mathrm{mg} \mathrm{L}^{-1}$ and $7.73 \mathrm{mg} \mathrm{L}^{-1}$, respectively.

\section{DISCUSSION}

Based on the results of this study it was possible to verify the glyphosate high toxicity, however, its commercial formulation Roundup Original ${ }^{\circledR}$, presented higher toxic effect. AMPA, the main metabolite of glyphosate, had a similar toxic effect than of glyphosate, The inert ingredient of the Roundup ${ }^{\circledR}$ Original could be responsible for the increased toxicity of the commercial compound.
It was verified the possibility of using the formulation in areas where the growth of floating aquatic macrophytes are not controlled, within limited concentration range and precision when spraying it, avoiding damage, to other the aquatic ecosystem species. However, even in non-toxic concentrations for global evaluation and for the organisms that were evaluated in this study, changes were evidenced in the reproductive dynamics of fish, snails, even though indirect consequences. Macrophytes are part of the ecosystem and when they do not survive, physico-chemical changes occur in the aquatic system. These changes are naturally compensated by environmental plasticity, nonetheless causing alterations in the biological community, as a greater proliferation of other groups.

It should be ensured that the herbicide will not be used in a site without macrophytes cover, or that these specific areas (without macrophytes cover) are not contaminated by drift during the spraying process. In these cases, the toxic effect can cause serious environmental damages. Complementary studies to evaluate the residual concentration of glyphosate and AMPA in water are fundamental, considering the high risk of its use to the environment and humans, as well as compliance of the regulations for water bodies.

\section{ACKNOWLEDGEMENTS}

The authors are grateful to the Foundation for Research Support of the State of Minas Gerais, the Department of Sanitary and Environmental Engineering of the Federal University of Minas Gerais, the SENAI Innovation and Technology Center and the Botanical Garden of the ZooBotanic Foundation of Belo Horizonte/MG.

\section{REFERENCES}

ABE, M.. 2014. ApplicationWork IC BR6-0006-032015 - Avaliação da Separação dos Ânions comuns, Oxihaletos, AMPA e Glifosato com Gradiente com Dosino em coluna Metrosep A Supp 7 - 250. Metrohm Pensalab Instrumentação Analítica LTDA.

AMARANTE Jr, OPA, SANTOS, TCR, BRITO, NM, RIBEIRO, ML. 2002. Glifosato: propriedades, toxicidade, uso e legislação. Quim. Nova, vol. 25, No 4, 589-593.

ARENZON, A, PEREIRA NETO, TJ, GERBER, W. 2011. Manual sobre toxicidade em efluentes industriais. Porto Alegre: CEP SENAI de Artes Gráficas Henrique d'ávila Bertaso.

ASSOCIAÇÃO BRASILEIRA DE NORMAS TÉCNICAS. 2007. NBR 15469. Ecotoxicologia aquática - Preservação e preparo de amostras.

ASSOCIAÇÃO BRASILEIRA DE NORMAS TÉCNICAS. 2016. 
NBR 12713. Ecotoxicologia Aquática - Toxicidade aguda Método de ensaio com Daphnia spp (Crustacea, Cladocera).

ASSOCIAÇÃO BRASILEIRA DE NORMAS TÉCNICAS. 2016. NBR 13373. Ecotoxicologia Aquática - Toxicidade crônica Método de ensaio com Ceriodaphnia spp (Crustacea, Cladocera). ASSOCIAÇÃO BRASILEIRA DE NORMAS TÉCNICAS. 2012. NBR 15411-2. Ecotoxicologia Aquática - Determinação do efeito inibitório de amostras aquosas sobre a emissão de luz de Vibrio fisheri (ensaio de bactéria luminescente).

ASSOCIAÇÃO BRASILEIRA DE NORMAS TÉCNICAS. 2016. NBR 15499. Ecotoxicologia Aquática - Toxicidade crônica de curta duração - Método de ensaio com peixes.

BERTOLETTI, E. 2009. Sensibilidade de Algumas Espécies de Peixes de água doce Utilizadas no Brasil. J. Braz. Soc. Ecotoxicol., v.4, n. 1-3, 9-13. http://dx.doi.org/10.5132/jbse.2009.01.002.

CONSELHO NACIONAL DO MEIO AMBIENTE - CONAMA. 2015. Resolução $n^{\circ} 467$ de 16 de julho de 2015. Dispõe sobre critérios para a autorização de uso de produtos ou de agentes de processos físicos, químicos ou biológicos para o controle de organismos ou contaminantes em corpos hídricos superficiais.

COSTA, RN, NOMURA, F. 2016. Measuring the impacts of Roundup Original on fluctuating asymmetry and mortality in a Neotropical tadpole. Hydrobiologia, 765:85-96. http://dx.doi. org/10.1007/s10750-015-2404-0.

FACCHINI, L. 2007. Pesticides poisoning in Brazil: the official notification system and challenges to conducting epidemiological studies. Ciência \& Saúde Coletiva, 12 (1): 25-38. http://dx.doi. org/10.1590/S1413-81232007000100008.

HABERKORN, SS, QUINIOU, F, NEDELEC, M, ROBERT, R, LIMON, G, BROISE, DL. 2008. In-situ microcosms, a tool for assessment of pesticide impacts on oyster spat (Crassostrea gigas). Ecotoxicology, 17:235-245. http://dx.doi.org/10.1007/ s10646-007-0190-9.

LEVIS, NA, JOHNSON, JR. 2015. Level of UV-B radiation influences the effects of glyphosate-based herbicide on the spotted salamander. Ecotoxicology, 24:1073-1086. http://dx.doi. org/10.1007/s10646-015-1448-2.

MAGALHÃES, DP, FERRÃO FILHO, AS. 2008. A Ecotoxicologia como ferramenta no biomonitoramento de ecossistemas aquáticos. Oecol. Bras., 12 (3): 355-381.

MIKÓ, Z, UJSZEGI, J, GÁL, Z, IMREI, Z, HETTYEY, A. 2015. Choice of experimental venue matters in ecotoxicology atudies: Comparison of a laboratory baseado em outdoor mesocosm. Experiment. Aquatic Toxicology, 20-30. http://dx.doi. org/10.1016/j.aquatox.2015.07.014.

ORGANIZATION FOR ECONOMIC COOPERATION AND DEVELOPMENT - OECD. 2006. 221. Lemna sp. Growth
Inhibition Test. In: Guidelines for the testing of chemicals, 23 mar. 2006. Disponível em: http://www.oecd.org/chemicalsafety/ testing/1948054.pdf. Acessado em: 18 de dezembro de 2016.

PESCE, S, BATISSON, I, BARDOT, C, FAJON, C, PORTELLI, C, MONTUELLE, B, BOHATIER, J. 2009. Reponse of spring and summer riverine microbial communities following glyphosate exposure. Ecotoxicology and Environmental Safety, 1905-1912. http://dx.doi.org/10.1016/j.ecoenv.2009.07.004.

ROCHA, TL, SANTOS, APR, SOARES, CMA, BORGES, CL, BAILÃO, AM, MORAIS, S MTS. 2015. Proteomic and histoáthological response in the gills of Poecilia reticulata exposed to glyphosate-based herbicide. Environmental Toxicology and Pharmacology, 175-186.

SIHTMAE, M, BLINOVA I, BERES, KH, KANARBIK, L, HEINLAAN, M, KAHRU, A. 2013. Ecotoxicological effects of different glyphosate formulations. Applied Soil Ecology, (72) 215-224. http://dx.doi.org/10.1016/j.apsoil.2013.07.005.

SILVA, AC, GUAZZELLI, VG, LOPES, FM, JUNIOR, ASV, CORCINI, CD, TAVARES, G, ROSA, CE. 2014. Effect of glyphosate on the sperm quality of zebrafish Danio rerio. Aquatic Toxicology, 322-326. http://dx.doi.org/10.1016/j. aquatox.2014.07.006.

TRINDADE, CRT, PEREIRA, AS, ALBERTONI, EF, PALMASILVA, C. 2010. Caraterização e importância das macrófitas aquáticas com ênfase nos ambientes limnicos do campus carreiros - FURG, Rio Grande, RS. Caderno de Ecologia Aquática, 5 (2): $1-22$.

TSUI, MTK, WANG, WX, CHU, LM. 2005. Influence of glyphosate and its formulation (Roundup ${ }^{\circledR)}$ on the toxicity and bioavailability of metals to Ceriodaphnia dubia. Environmental Pollution, (138) 59-68. http://dx.doi.org/10.1016/j.envpol.2005.02.018.

VERA, MS, FIOR, ED, LAGOMARSINO, L, SINISTRO, R, ESCARAY, R, IUMMATO, MM, JUAREZ, A, MOLINA, MCR, TELL, G, PIZARRO, H. 2012. Direct and indirect effects of the glyphosate formulation Glifosato Atanoron freshwater microbial communities. Ecotoxicology, 21:1805-1816. http:// dx.doi.org/10.1007/s10646-012-0915-2.

VERA, MS, FIOR, ED, LAGOMARSINO, L, SINISTRO, R, ESCARAY, R, IUMMATO, MM, JUAREZ, A, MOLINA, MCR, TELL, G, PIZARRO, H. 2010. New evidences of Roundup (glyphosate formulation) impact on the periphyton community and the water quality of freshwater ecosystems. Ecotoxicology, 19:710-721. http://dx.doi.org/10.1007/s10646-009-0446-7.

YUSOF, S, ISMAIL, A, ALIAS, MS. 2014. Effect of glyphosatebased herbicide on early life stages of java medaka (Oryzias javanicus): A potential tropical test fish. Marine Pollution Bulletin, 494 - 498. http://dx.doi.org/10.1016/j.marpolbul.2014.03.022. 